\title{
PENINGKATAN PRODUKTIVITAS DAN MANAJEMEN USAHA PADA PENGRAJIN ANYAMAN ROTAN MELALUI IMPLEMENTASI TEKNOLOGI TEPAT GUNA
}

\section{INCREASING PRODUCTIVITY AND BUSINESS MANAGEMENT ON RATTAN WEAVING CRAFTSMEN TH ROUGH IMPLEMENTATION OF APPROPRIATE TECHNOLOGY}

\author{
${ }^{1)}$ A. Khoirul Anam, ${ }^{2)}$ Edi Susilo \\ 1) Program Studi Manajemen, ${ }^{2)}$ Program Studi Ekonomi Islam, \\ Universitas Islam Nahdlatul Ulama Jepara \\ Jl. Taman Siswa Tahunan Jepara, Jawa Tengah \\ 1) email: anam@unisnu.ac.id, ${ }^{2)}$ email: edisusilo@unisnu.ac.id
}

\begin{abstract}
ABSTRAK
Permasalahan utama yang dihadapi oleh mitra program yaitu pada bidang produksi, pemasaran serta pengeloaan usaha. Pemasaran dilakukan langsung ke pelanggan, secara online serta melalui media sosial namun masih sangat terbatas. Dalam bidang produksi, peralatan mesin yang digunakan sangat sederhana serta kapasitas produksi yang mampu dihasilkan pengrajin masih relatif kecil serta belum bisa memenuhi permintaan konsumen dan kebutuhan pasar. Tujuan dari kegiatan ini adalah untuk meningkatkan produktivitas dan manajemen usaha pengrajin anyaman rotan melalui implementasi teknologi tepat guna. Metode pelaksanaan kegiatan adalah pemberdayaan masyarakat melalui kegiatan identifikasi dan implementasi teknologi tepat guna serta pendampingan pengelolaan usaha. Hasil kegiatan menunjukkan pengrajin dapat meningkatkan produktivitasnya; produk yang dihasilkan lebih bagus dari segi estetika karena lebih presisi; proses pengerjaan lebih cepat sehingga dapat menyelesaikan pengerjaan tepat waktu sesuai pesanan; dan pembenahan manajerial telah dilakukan dengan baik. Inovasi produk dan pengembangan media pemasaran online.
\end{abstract}

Kata kunci : Pengrajin Anyaman Rotan, Teknologi Tepat Guna, Inovasi Produk

\begin{abstract}
The main problem faced by the partners are production, marketing and business management. Marketing is conducted through directly to costumer, online, and social media but still very limited. In a Production, product capacity that can be processed by craftsmen is still relatively small and has not been able to supply consumer demand and market needs.The objective of this activity is to increase productivity and business management of rattan weaving craftsmen through the implementation of appropriate technology. To solve that problems, the partners agree to increase the productivity and implementation of appropriate technology. Therefore, methods of implementation of activities carried out in the form of community empowerment through the identification and implementation of appropriate technology and business management assistance. Through this service of community; craftsmen could increase their productivity; the products are produced better in terms of aesthetics because it is more precise; proccess of working faster so that the order could finish on time; and managerial improvement has been done well; and it also has been done with some innovations of the products and media development of online marketing.
\end{abstract}

Keyword : Rattan Weaving Craftsmen, Appropriate Technology, And Product Innovation

Submitted:4 September 2017 Revision : 19 Juni 2018 Accepted : 30 Juni 2018 


\section{PENDAHULUAN}

Sentra kerajinan anyaman rotan di kabupaten Jepara berada di wilayah Kecamatan Welahan Kabupaten Jepara, atau lebih tepatnya sekitar $29 \mathrm{KM}$ ke arah selatan dari pusat kota Jepara. Sentra kerajinan rotan ini merupakan salah satu dari 12 industri kecil dan menengah yang ada di Kabupaten Jepara dengan unit usaha sejumlah 846 unit serta mampu menyerap tenaga kerja sejumlah 4.665 orang (BPS Kabupaten Jepara, 2016). Perkembangan dari sentra kerajinan anyaman rotan ini tidak terlepas dari keahlian masyarakat di wilayah Kecamatan Welahan yang dimiliki secara turun temurun, menjadikan kerajinan anyaman rotan menjadi produk unggulanuntuk dikembangkan. Menurut Nuswantoro dalam Pradigda (2016) produk unggulan daerah merupakan suatu barang atau jasa yang dimiliki dan dikuasai oleh suatu daerah, yang mempunyai nilai ekonomis dan daya saing tinggi serta menyerap tenaga kerja dalam jumlah besar, yang diproduksi berdasarkan pertimbangan kelayakan teknis (bahan baku dan pasar), talenta masyarakat dan kelembagaan (penguasaan teknologi, kemampuan sumberdaya manusia, dukungan infrastruktur, dan kondisi sosial budaya setempat) yang berkembang di lokasi tertentu.

Pengembangan kerajinan rotan tidak hanya tersedia dalam produk akhir yang berbahan baku rotan alam saja, pada berbagai produk yang dihasilkan seperti furniture, hiasan interior, perkakas, dan souvenir, banyak dipadukan dengan beberapa bahan baku lainnya.Selain dibuat dengan menggunakan bahan rotan alam juga dibuat kerajinan rotan dengan menggunakan rotan sintetis. Rotan sintetis ini terbuat dari politilen yang produksi secara kimiawi di pabrik, tujuan dari rotan sintetis ini salah satunya untuk menggantikan keberadaan rotan asli yang ketersediaannya mulai mengalami penurunan pasokan serta mahalnya harga rotan alam, sehingga mulai banyak digunakan bahan rotan sintetis (Palupi, Utomo, \& Nuradhi, 2017).

Bahan baku yang digunakan dalam proses produksi meliputi rotan alam, rotan sintetis, eceng gondok, debog, kayu, alumunium, besi, stainlies, busa, kain oscar dan kain waterpruf. Bahan baku yang dibutuhkan tersebut berasal dari berbagai wilayah, untuk rotan sintetis didapat dari Jakarta, Surabaya dan Semarang sedangkan bahan Rotan alam didapat dari Kalimantan. Adapun untuk bahan-bahan yang lainnya didapatkan dari wilayah sekitar Kabupaten Jepara. Permasalahan yang di hadapi berkaitan dengan bahan baku berupa ketersediaan bahan baku utama seperti rotan alam dan rotan sintetis susah didapat serta lamanya proses pengiriman bahan dari waktu pemesanannya, serta harga-harga bahan yang cenderung naik fluktuatif.

Persoalan lainnya yang dihadapi oleh pengrajin yaitu dalam bidang produksi, pemasaran serta pengeloaan usaha.Pemasaran masih menggunakan model pemasaran langsung ke pelanggan. Pengrajin langsung melakukan pemasaran sendiri ke pelanggan yang ada dibeberapa daerah, meskipun sudah ada upaya pemasaran online dan melalui meda sosial namun masih sangat terbatas. Nurcahyanie, Suharyanto, \& Suparman (2017) mengatakan persoalan pada kerajinan bahan anyam-anyaman, antara lain berkaitan dengan standar kualitas produk mulai dari bahan baku, proses pengerjaan, proses pengemasan, sampai pada kelayakan di tangan konsumen.

Dalam bidang produksi, pengrajin sebetulnya telah menggunakan beberapa peralatan mesin sederhana dalam proses produksinya. Kapasitas produksi yang mampu dihasilkan pengrajin masih relatif kecildibandingkan dengan kebutuhan pasar, serta kualitas produk yang dihasilkan juga belum standar kurang bisa memenuhi permintaan pasar, sehingga 
perlu adanya upaya inovasi teknologi dalam produk serta proses produksi. Bigliardi et al (2011) menyatakan bahwa inovasi produk, proses dan pemasaran merupakan jenis inovasi yang banyak berlaku pada usaha mikro dan kecil. Hal ini menjadi masalah utama yang dihadapi oleh pengrajin.

Oleh karena itu tujuan dari program ini yaitu meningkatkan produktivitas dan manajemen usaha pada pengrajin anyaman rotan melalui implementasi teknologi tepat guna.

\section{METODE}

Program pengabdian diarahkan pada dua tahap, yaitu 1) Identifikasi dan implementasi teknologi tepat guna dan 2) Pendampingan pengelolaan usaha.

1. Identifikasi dan implementasi teknologi tepat guna

Pada tahap ini dilaksanakan identifikasi permasalahan yang dihadapi oleh pengrajin, dalam bidang produksi berkaitan dengan kapasitas produksi yang rendah belum bisa memenuhi kebutuhan pasar akan produk kerajinan rotan, sehinggadiperlukan implementasi teknologi tepat guna yang dapat menunjang peningkatan kualitas dan kapasitas produksi. Kendala yang dihadapi pengrajin dalam proses produksi ini meliputi proses pembuatan rangka produk dan proses finishing produk jadi.

Beberapa produk membutuhkan rangka dari bahan besi maupun stainlis, dalam pembuatan rangka produk dibutuhkan proses pengelasan dan pembengkokan. Proses pengelasan selama ini diserahkan kepada bengkel las yang berada di wilayah sekitar pengrajin,oleh pengrajin sulit mengontrol kualitas pengelasan dan membutuhkan waktu yang cukup lama, sehingga dibutuhkan teknologiberupa mesin las listrik. Sedangkan pada proses pembengkokan, oleh pengrajin selama ini dilakukan secara manual sehingga hasil lekukannya kurang presisi dan membutuhkan waktu yang cukup lama sehingga dibutuhkan teknologi berupa mesin roll bending rotan.

Sedangkan dalam proses finishing, beberapa produk yang dihasilkan pengrajin, beberapa diantaranya menggunakan rotan alam yang di rendam dalam lumpur dalam waktu kurang lebih satu minggu, ini dilakukan untuk mendapatkan corak yang natural atau dalam produk tertentu menggunakan bahan tambahan lainnya, sehingga dalam proses finishing akhir memerlukan pembersihan, oleh pengrajin selama ini dilakukan pembersihan manual sehingga hasilnya kurang bersih dan membutuhkan waktu yang cukup lama, sehingga dibutuhkan teknoligi berupa mesin pembersih jet cleaning yang lebih otomatis dan memiliki daya pembersih yang lebih bagus.

Implemetasi teknologi tepat guna pada kerajinan anyaman rotan ini untuk peningkatan efisiensi proses produksi, serta diharapkan dapat meningkatkan kuantitas dan kualitas produk yang dihasilkan.

2. Pendampingan pengelolaan usaha

Berkaitan dengan permasalahan desain, oleh pengrajin masih menggantungkan desain yang ada di pasar atau sesuai permintaan konsumen, terutama pada jenis produk furniture rotan, pengrajin belum memiliki ciri khas tersendiri, ketergantungan pada desain produk ini menjadikan pengrajin sulit menyesuaikan desain yang ada karena banyaknya desain yang ada dan spesifikasi yang sering berubah. Belum dimilikinya keahlian desain dan inovasi produk oleh pengrajin, 
maka dilakukan pendampingan tentang inovasi desain produk rotan.

Pada aspek manajemen usaha selama ini pengelolaan manajemen usaha dilakukan oleh pemilik sendiri mengelola administrasi, akuntansi dan keuangan serta pemasaran. Persoalan yang dihadapi dengan banyaknya pesanan produk dengan berbagai varian dan spesifikasi dituntut ketepatan waktu dalam penyelesaiannya, selama ini manajerial usaha belum dilakukan pengelolaan dengan baik.Solusi yang ditawarkan dengan menyusun sistem administrasi dengan memberikan pendampingan penerapan sistem administrasi maupun sistem akuntansi, guna mempermudah pengrajindalam menyusun dan mengontrol pekerjaan, serta memberikan kemudahan dalam mengambil keputusan dalam perencanaan usaha.

Sedangkan untuk aspek pemasaran, selama ini pengrajin melakukan pemasaran secara langsung ke konsumen atau bergantung dengan perusahaan lain dengan cara menjual produk ke perusahaan yang lebih besar.Solusi yang ditawarkan dengan memberikan pendampingan dan fasilitasi pemasaran online, guna mendukung sistem pemasaran yang ada saat ini.

\section{HASIL DAN PEMBAHASAN}

Berdasarkan pada analisis situasi atas persoalan yang dihadapi oleh pengrajin serta solusi yang ditawarkan guna menyelesaikan persoalan prioritas tersebut, dalam hal ini dilakukan dalam dua tahapan kegiatan meliputi identifikasi dan implementasi teknologi tepat guna dan pendampingan penglolaan usaha.

\section{Tahap Indentifikasi dan implementasi teknologi tepat guna}

Pelaksanaan program dimulai melalui kegiatan survei awal persiapan pelaksanaan pengabdian. Pada kegiatan ini telah dilakukan pertemuan awal dengan pihak pengrajin, melalukan identifikasi persoalan utama yang memerlukan penyelesaian dan kebutuhan teknologi tepat guna yang dapat digunakan dalam menunjang proses produksi. Hasil identifikasi persoalan dalam bidang produksi diperoleh prioritas utama yang memerlukan penyelesaian yaitu proses pembuatan rangka produk dan proses finishing produk jadi.Adapun kebutuhan teknologi yang diidentifikasi dan menjadi kebutuhan pengrajin guna membantu menyesaikan kendala dalam bidang produksi meliputi : Welding Machine, Grenda Maktec, Jet Cleaner, Air Compressor, Pneumatic Brad Nailer \& Stapler dan mesin roll bending rotan. Seluruh peralatan diserahkan langsung oleh ketua program pengabdian kepada UKM Rotan Asia dan UKM Rotan Indah Jepara (gambar 1).

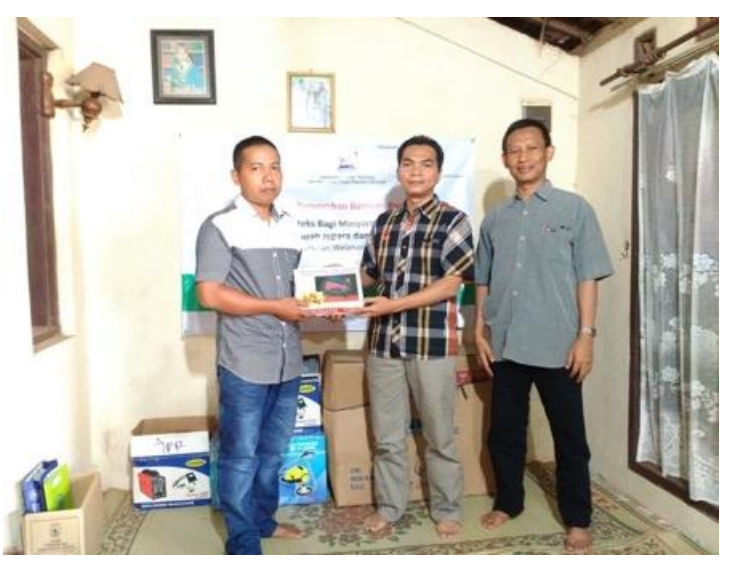

Gambar 1. Penyerahan bantuan peralatan

Untuk menunjang proses produksi, pada tahap pembuatan rangka produk, dibutuhkanteknologi yang digunakan untuk membuat profil lengkungpada rangka produk, melalui kegiatan ini dibuat teknologi tepat guna dalam bentuk mesin roll bending yang dirakit dengan spesifikasi sebagai berikut: rangka 
berbahan besi dengan ukuranpanjang 70 $\mathrm{cm}$, lebar $37 \mathrm{~cm}$ dan tinggi $79 \mathrm{~cm}$; mesin penggerak menggunakan dinamo bertenaga diesel dan listrik, sehingga pada saat listrik PLN padam bisa menggunakan diesel; dapat digunakan untuk membuat lekukan sederhana hingga lingkaran pada rotan dan besi. Mesin tersebut menjadi teknologi tepat guna bagi UKM (gambar 2), dirakit sesuai dengan kebutuhan pengrajin dan dapat disesuaikan posisinya, mudah dalam perawatan serta tidak tergantung pada produk dari pabrik.

Berdasarkan pada hasil monitoring yang dilakukan terhadap implementasi mesin roll bending tersebut diperoleh bahwa, pada awalnya pengrajin mengerjakan proses pembuatan rangka produk dilakukan dengan cara manual menggunakan alat catok (alat pembengkok yang terbuat dari kayu), menggunakan tenaga manusia, sehingga hasilnya kurang bagus dan membutuhkan waktu cukup lama, dengan implementasi teknologi baru ini, didapatkan hasil yang lebih bagus dari segi estetika karena lebih presisi serta proses pengerjaan yang lebih cepat dan efisien, dengan konstruksi peralatan yang sederhana, mudah dalam pengoperasiannya(Mustakim, 2016). Dari segi efisiensi waktu pengerjaan, untuk membuat satu lekukan sederhana bisa dikerjakan 15 menit lebih cepat dibandingkan apabila dikerjakan secara manual.

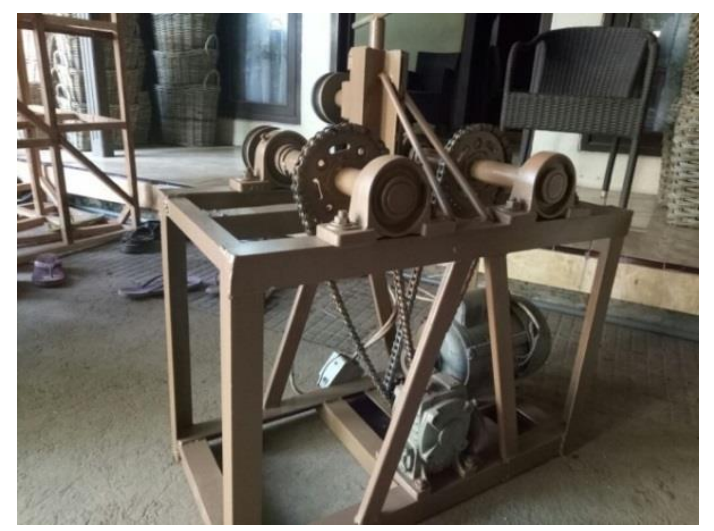

Gambar 2. Mesin roll bending rotan hasil perakitan
Selain membuat anyaman rotan dalam bentuk souvenir, pengrajin juga mengerjakan produk berupa furniture rotan seperti kursi, ayunan, daybed, dipan, dsb. Dalam proses pebuatan rangka produk dibutuhkan proses pengelasan. Dalam proses pengelasan ini sebelumnya pengrajin menyerahkannya kepada bengkel las yang berada di wilayah sekitar pengrajin. Kendala yang dihadapi yaitu kontrol kualitas hasil pengelasan dan membutuhkan waktu yang lama karena harus mengantri, sehingga untuk penyelesaian produk tepat waktu menjadi terkendala. Melalui implementasi teknologi baru berupa las listrik (gambar 3), oleh pengrajin dapat mengerjakan proses pengelasan sendiri, dengan hasil yang lebih baik karena dapat langsung dilakukan kontrol mulai dari proses pengerjaannya dan waktu pengerjaan yang lebih cepat, sehingga pengrajin dapat menyelesaikan pengerjaan tepat waktu sesuai pesanan.

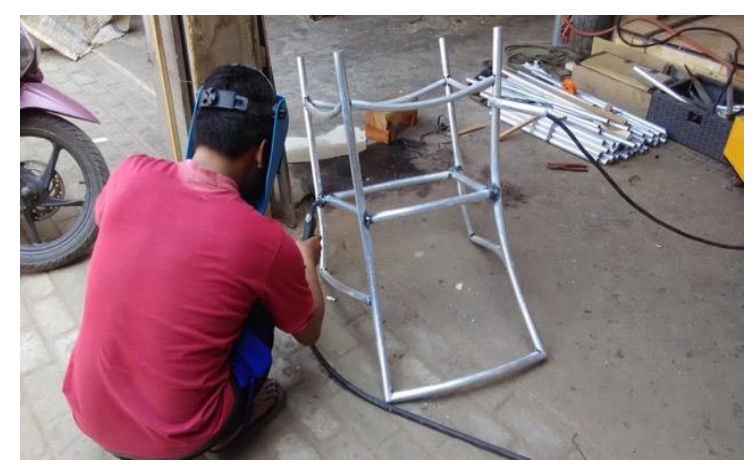

Gambar 3. Proses pengelasan pada produk furniture rotan

Sedangkan pada tahap finishing produk jadi, kendala yang dihadapi oleh pengrajin yaitu proses pembersihan produk dari kotoran yang menempel pada rotan. Pada pembuatan anyaman keranjang rotan, bahan baku rotan yang akan digunakan, sebelumnya dilakukan perendalam rotan di lumpur selama kurang lebih satu minggu, hal ini dilakukan untuk mendapatkan tekstur rotan yang terlihat lebih natural, kemudian baru dilakukan proses 
penganyaman menjadi produk keranjang rotan. Proses finishing produk jadi, dilakukan pembersihan terhadap lumpur yang masih menempel. Pada tahap ini, sebelumnya pengrajin membersihkannya dengan cara manual menggunakan peralatan sikat sehingga hasilnya kurang bersih dan membutuhkan waktu yang cukup lama, dengan implementasi teknologi mesin jet cleaner, proses pembersihan menjadi lebih cepat dan hasilnya lebih bersih (gambar 3). Untuk setiap keranjang dengan implementasi teknologi baru ini bisa dikerjakan 5 menit lebih cepat dibandingkan apabila dikerjakan secara manual.

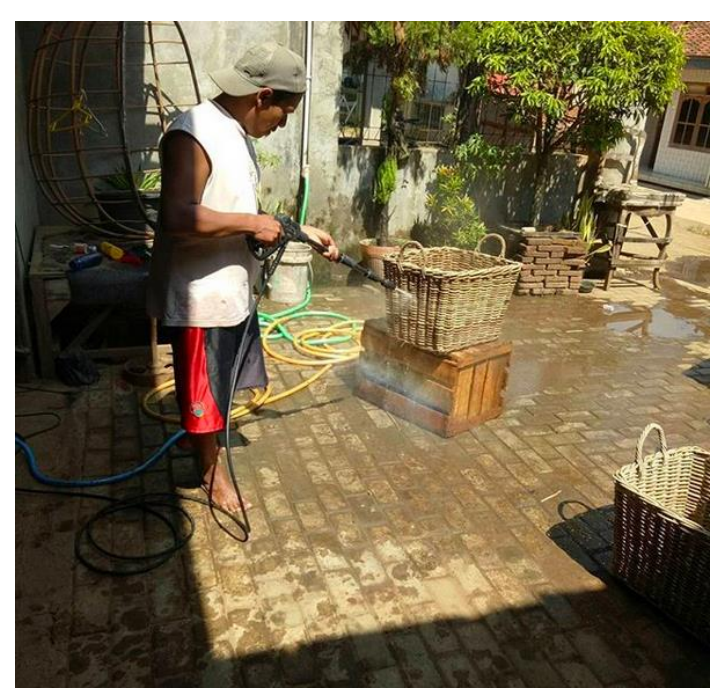

Gambar 4: Implementasi jet cleaner pada proses pembersihan produk

\section{Tahap Pendampingan pengelolaan usaha}

Persoalan bidang manajemen usaha yang dihadapi oleh pengrajin, dalam hal ini manajemen usahanya masih dikelola dengan cara tradisional, belum dimilikinya sistem administrasi dan pengelolaan akuntansi yang terkomputerisasi, sehingga untuk mengetahui secara tepat perkembangan usaha belum bisa dilakukan.
Selain masalah pengelolaan manajerial usaha, disamping itu juga persoalan desain dan inovasi produk, belum adanya inovasi dan pengembangan desain produk yang baru karena keterbatasan pengetahuan desain produk. Produk yang dihasilkan sesuai dengan pesanan belum ada inovasi untuk membuat desain sendiri. Permintaan atas desain dan spesifikasi produk juga tidak bisa dipenuhi oleh pengrajin karena keterbatasan kemampuan desain produk sesuai permintaan pesanan.

Melalui proses pendampingan dalam program pengabdian kepada masyarakat ini dilakukan pelatihan pengelolaan usaha dan motivasi usaha serta pengembangan desain dan inovasi produk. Juga dilaksanakan pendampingan dan fasilitasi pemasaran produk, melalui pengembangan media pemasaran online baik malalui website, instragram maupun social media lainnya.

Berdasarkan pada hasil monitoring yang dilakukan menunjukkan bahwa pengrajin setidaknya telah melakukan pembenahan manajerial dengan baik, dengan menyediakan ruangan yang difungsikan khusus sebagai kantor untuk pengelolaan usaha, telah dilakukan pembukuan keuangan, secara bertahap telah dilakukan inovasi produk serta telah dilakukan pengembangan media pemasaran online.

\section{SIMPULAN}

Adapun kesimpulan pada pelaksanaan kegiatan pengabdian kepada masyarakat ini antara lain: melalui implementasi teknologi tepat guna, produk yang dihasilkan lebih bagus dari segi estetika karena lebih presisi. Pengrajin dapat mengerjakan proses pengelasan sendiri, dengan hasil yang lebih baik karena dapat langsung dilakukan kontrol mulai dari proses pengerjaannya, dalam finishing akhir proses pembersihan dapat dikerjakan lebih cepat dan hasilnya lebih bersih, sehingga pengrajin dapat menyelesaikan pengerjaan tepat waktu sesuai pesanan.Melalui program 
pengabdian ini, pengrajin telah melakukan pembenahan manajerial dengan baik, secara bertahap telah dilakukan inovasi produk serta telah dilakukan pengembangan media pemasaran online.

\section{UCAPAN TERIMAKASIH}

Program $\begin{gathered}\text { pengabdian } \\ \text { dilaksanakan } \\ \text { merupakan }\end{gathered}$
skema
tim pengabdian Iptek Bagi Masyarakat $(\mathrm{IbM})$ mengucapkan terimakasih
kepada:

1. Kementrian Ristek DIKTI, Direktorat Riset dan Pengabdian Kepada Masyarakat yang telah mendanai pelaksanaan program pengabdian kepada masyarakat;

2. Lembaga Penelitian dan Pengabdian Kepada Masyarakat (LPPM) Universitas Islam Nahdlatul Ulama (UNISNU) Jepara yang telah mengkoordinir pelaksanaan kegiatan pengabdian masyarakat;

3. UKM Rotan Indah Jepara dan UKM Rotan Asia, sebagai mitra program dalam pelaksanaan program IbM, dan telah secara aktif ikut berpartisipasi dalam program pengabdian ini.

\section{DAFTAR PUSTAKA}

Bigliardi, B., Pierluigi, C., \& Dormio, A. I. (2011). Innovative Caharcteristics of Small and Medium Enterprises. Journal of Technology Management \& Innovation, 6 (22), 83-93.

Kabupaten Jepara Dalam Angka 2016. (2016). Jepara: Badan Pusat Statistik Kabupaten Jepara.

Mustakim. (2016). Perancangan Mesin Roll Bending Pembentuk Profil Lingkaran Untuk Kerajinan Rotan. Malang: Institutional Repository, Universitas Muhammadiyah Malang.
Nurcahyanie, Y. D., Suharyanto, \& Suparman. (2017). Peningkatan Kualitas Sumber Daya Manusia Pada Industri Kerajinan Anyaman Untuk Pemenuhan Pasar Ekspor. Penamas Adi Buana, 2 (3).

Palupi, A., Utomo, T., \& Nuradhi, L. (2017). Perangcangan Furniture Berbahan Rotan dan Fasilitas Pendukungnya. KREASI, 2 (1), 5672.

Bigliardi, B., Pierluigi, C., \& Dormio, A. I. (2011). Innovative Caharcteristics of Small and Medium Enterprises. Journal of Technology Management \& Innovation, 6 (22), 83-93.

Kabupaten Jepara Dalam Angka 2016. (2016). Jepara: Badan Pusat Statistik Kabupaten Jepara.

Mustakim. (2016). Perancangan Mesin Roll Bending Pembentuk Profil Lingkaran Untuk Kerajinan Rotan. Malang: Institutional Repository, Universitas Muhammadiyah Malang.

Nurcahyanie, Y. D., Suharyanto, \& Suparman. (2017). Peningkatan Kualitas Sumber Daya Manusia Pada Industri Kerajinan Anyaman Untuk Pemenuhan Pasar Ekspor. Penamas Adi Buana, 2 (3).

Palupi, A., Utomo, T., \& Nuradhi, L. (2017). Perangcangan Furniture Berbahan Rotan dan Fasilitas Pendukungnya. KREASI, 2 (1), 5672.

Pradigda, E. A. (2016). Strategi Perencanaan Pembangunan Industri Berbasis Produk Unggulan Daerah, Studi pada Dinas Perindustrian dan Perdagangan Kabupaten Blitar. Paradigma, 5 (3), 112-131. 